\title{
A Public Program to Evaluate Commercial Soybean Cultivars for Pathogen and Pest Resistance
}

\author{
Shilpi Chawla \\ University of Illinois, National Soybean Research Center, Department of Crop Sciences, Urbana
}

Charles R. Bowen

USDA-ARS, National Soybean Research Center, Urbana

Tara L. Slaminko

University of Illinois, National Soybean Research Center, Department of Crop Sciences, Urbana

Houston A. Hobbs

University of Illinois, Department of Crop Sciences, Urbana

Glen L. Hartman

USDA-ARS and University of Illinois, National Soybean Research Center, Department of Crop Sciences, Urbana

\begin{abstract}
The soybean crop is one of the most important crops worldwide, as the seeds are used for both protein meal and vegetable oil. Soybean acreage covers an estimated $6 \%$ of the arable land in the world, and since the 1970 s, soybean has had the highest percent increase of hectares in production compared to any other major crop (14). The United States leads the world in production, with about $35 \%$ of the total. In 2011, the United States produced 83.1 million metric tons on 29.8 million ha for a value of $\$ 35.8$ billion (www.nass.usda.gov). As demand for soybean continues to rise, the production area and worldwide trade are likely to increase.

Biotic constraints, such as pathogens, pests, and weeds, can be detrimental to soybean production, causing significant negative impacts to yield. Pathogens and pests of soybean infect and/or attack all parts of the plants from roots to seeds, and the extent of economic plant damage depends upon many factors including host susceptibility (10). To successfully reduce losses caused by pathogens and pests, various practices such as cultural and seed sanitation techniques, pesticide applications, and deployment of resistance are used (10). Today, most soybean growers in the United
\end{abstract}

Corresponding author: Glen L. Hartman, USDA-ARS and University of Illinois, National Soybean Research Center, Department of Crop Sciences, Urbana; E-mail: ghartman@illinois.edu

Current address of third author: DuPont Pioneer, Crop Genetics Research \& Development, 985 County Road 300, Ivesdale, IL 61851.

Trade and manufacturers' names are necessary to report factually on available data; however, the USDA neither guarantees nor warrants the standard of the product, and the use of the name by USDA implies no approval of the product to the exclusion of others that may also be suitable.

http://dx.doi.org/10.1094/PDIS-05-12-0479-FE

This article is in the public domain and not copyrightable. It may be freely reprinted with customary crediting of the source. The American Phytopathological Society, 2013.
States purchase commercial soybean cultivars advertised by seed companies with disease- and pest-resistance.

For many years, public institutions have conducted regional yield trials on both private and public sector soybean cultivars. This information is usually presented in regional reports, at growers' meetings, and on websites. The purpose of these public trials is to provide soybean growers with data on agronomic traits, primarily yield, so they can compare and select soybean cultivars that will perform well in their region. In Illinois, the University of Illinois Variety Testing Program created a public database for growers (http://vt.cropsci.illinois.edu/soybean.html). This program started in 1969, and soybean cultivars are now evaluated at 13 locations throughout the state. In 2011, 516 cultivars were entered into the Variety Testing Program and planted in multiple replicated locations, with a total of 7,641 plots planted and harvested.

Prompted in part by disease reports on the cultivars entered into the University of Illinois Variety Testing Program, the Illinois Soybean Association (www.ilsoy.org) began providing funds in 1998 to obtain additional information from the trials to benefit growers in the state. The program supported by the Illinois Soybean Association, called the Varietal Information Program for Soybeans (VIPS), is an evaluation program that disseminates results through an online database consisting of pathogen and pest evaluations, seed quality information, and yield for soybean cultivars entered in the University of Illinois Variety Testing Program.

A number of research professionals contribute to VIPS, including specialists in agronomy, nematology, and plant pathology located in the Department of Crop Sciences at the University of Illinois and in the Department of Plant, Soil Science and Agricultural Systems at Southern Illinois University. This cooperative team of researchers conducts independent, objective, and unbiased evaluations that enable growers to effectively compare the performance of hundreds of soybean cultivars. Data are presented online at the VIPS website (www.vipsoybeans.org), where users can customize queries by company, location, specific resistance gene, and pathogen and pest assessments to choose cultivars that meet their 
production needs. For example, one producer in Illinois commented that: "VIPS helps me choose varieties that will perform well on my farm in East Central Illinois. I have lost yield to sudden death syndrome in the past, and I like that VIPS makes it easy to find varieties with good resistance." The website also has links to key crop protection information (insect, pathogen, and weed management) and other soybean production variety trials from other states. The focus of our article is to describe the VIPS pathogen and pest evaluations that we conduct, and to provide a brief overview of the Variety Testing Program and VIPS.

\section{Soybean Variety Testing Program}

The researchers in the Soybean Variety Testing Program conduct replicated field trials and evaluate these plots for agronomic characteristics such as height, lodging, maturity, and yield. In addition to standard yield trial data, protein and oil content are analyzed from samples collected from each plot. The Variety Testing

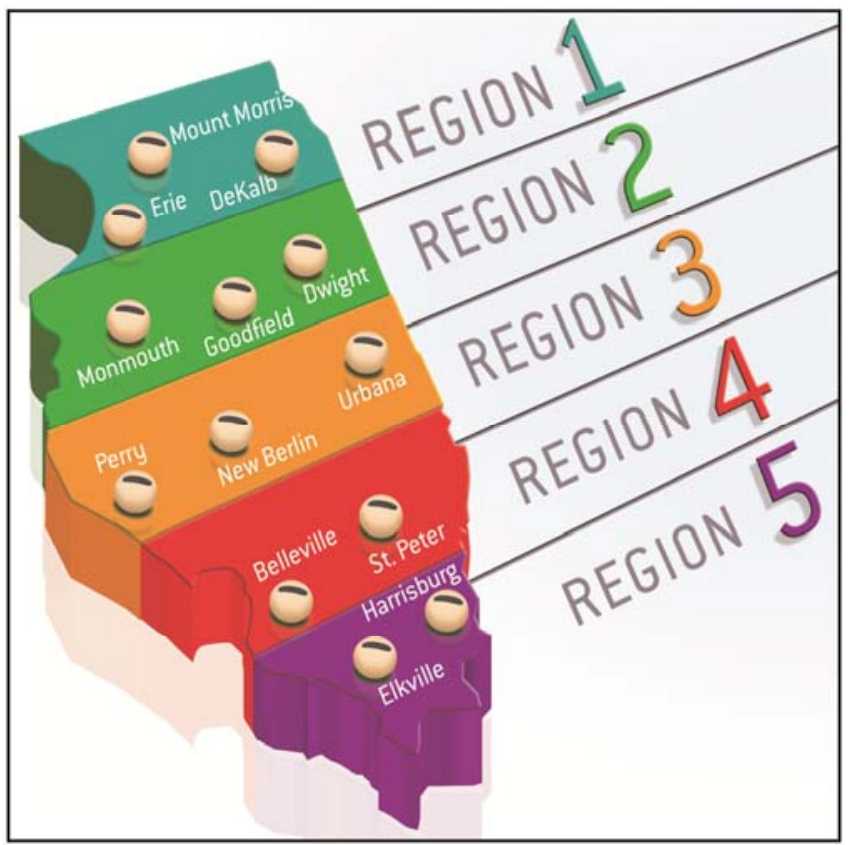

Fig. 1. Soybean growing regions of Illinois showing 13 field locations of the Soybean Variety Testing Program. Graphic courtesy Illinois Soybean Association.
Program utilizes 13 nonirrigated testing sites throughout the state that have been selected to represent Illinois soils and soybean maturity zone differences with earlier maturing cultivars planted to the north and later maturing cultivars planted to the south (Fig. 1). Cultivars are assigned into trials based on their maturity ratings and postemergence herbicide (glyphosate) treatment classification provided by the seed companies. Between 500 and 900 cultivars were entered into testing each year from 1998 to 2011 (Table 1). Soybean seed companies enter cultivars into the Variety Testing Program primarily to evaluate the performance of new cultivars or confirm performance of existing cultivars. Occasionally, entries are advanced breeding lines that need further testing before being released as cultivars, and are all referred to as cultivars in this article. Since Variety Testing cultivars may not include all cultivars of interest to Illinois farmers, the Illinois Soybean Association submits additional cultivars for evaluation based on a spring survey of soybean growers. In 2011, for example, there were 180 "producer-nominated" cultivars. In addition to these, historical public glyphosate intolerant cultivars from Illinois, Iowa, and Missouri served as long-term checks.

Companies first submit cultivar entries to the Variety Testing Program in February. Public cultivars from Illinois and Iowa breeding programs also are included. The seeds are packaged for field experiments and for distribution to VIPS cooperators. The final list of cultivars is completed in May. Seed companies are required to fill out forms that include information about agronomic traits (maturity group, flower color, hilum color, and pubescence color), any seed treatment that has been applied, and Phytophthora root rot resistance genes if known. Electronic files and seeds are distributed to the cooperating VIPS researchers with a unique multi-year identification number and one year four digit identifier to facilitate data exchange.

\section{Varietal Information Program for Soybeans (VIPS)}

VIPS was developed from the Soybean Variety Testing Program to provide soybean producers with a means to compare cultivars from multiple companies. Using the Variety Testing Program cultivars, VIPS has access to a broad collection of important commercial cultivars suited for soybean production in Illinois and neighboring states. Soybean cultivars entered into the program are predominately maturity groups II, III, and IV, which are grown in regions where most soybean production occurs in the United States (www.nass.usda.gov). VIPS research provides data on protein and oil content, and cultivar responses to key pathogens and pests of soybean (www.vipsoybeans.org). Using the database on the web-

Table 1. Number of commercial soybean seed companies, soybean cultivars, and website visits for the University of Illinois Varietal Information Program for Soybeans from 1998 to 2011

\begin{tabular}{|c|c|c|c|c|}
\hline \multirow[b]{2}{*}{ Year } & \multirow{2}{*}{$\begin{array}{l}\text { Number of companies } \\
\text { participated in VIPS }\end{array}$} & \multicolumn{2}{|c|}{ Number of cultivars } & \multirow{2}{*}{$\begin{array}{r}\text { Number of } \\
\text { website hits }\end{array}$} \\
\hline & & Conventional & Glyphosate-tolerant & \\
\hline 1998 & 67 & 489 & 328 & \\
\hline 1999 & 68 & 329 & 452 & \\
\hline 2000 & 59 & 338 & 447 & \\
\hline 2001 & 61 & 164 & 517 & \\
\hline 2002 & 60 & 96 & 544 & \\
\hline 2003 & 70 & 134 & 660 & \\
\hline 2004 & 72 & 129 & 717 & \\
\hline 2005 & 67 & 106 & 661 & \\
\hline 2006 & 65 & 67 & 620 & \\
\hline 2007 & 64 & 57 & 544 & \\
\hline 2008 & 62 & 66 & 552 & 47,456 \\
\hline 2009 & 57 & 149 & 507 & 69,410 \\
\hline 2010 & 42 & 169 & 419 & 94,917 \\
\hline 2011 & 46 & 109 & 407 & 119,416 \\
\hline
\end{tabular}

a www.vipsoybeans.org.

b The VIPS website was started in 2008. 
site, the user is able to make cultivar comparisons and to customize searches to meet production needs.

\section{Pathogen and Pest Evaluations}

Soybeans cultivars have been evaluated for resistance to a total of 12 pathogens and pests from 1998 to 2011 (Table 2). Not all of these have been used to evaluate soybean cultivars in VIPS each year, but a few diseases like Phytophthora root rot, Sclerotinia stem rot, soybean aphid, Soybean mosaic virus, and sudden death syndrome have been evaluated the most consistently. Five soybean pathogens or pests were used to evaluate the VIPS cultivars for resistance in the greenhouse in 2011 (Table 3). In addition to these evaluations, other researchers at the University of Illinois and Southern Illinois University use cultivars entered into VIPS to test for soybean cyst nematode and/or root knot nematode resistance (not addressed in this article). Pathogens and pests evaluated each year are selected based on their perceived economic importance and relevance for Illinois producers. The techniques used for resistance evaluations are selected based on reliability of the results and availability of resources (i.e., time, labor, greenhouse space, and expertise). In addition to the greenhouse and laboratory evaluations, resistance evaluations are assessed at the 13 Variety Testing Program locations when disease pressure is sufficient and widespread.

Greenhouse trials are conducted in the University of Illinois Plant Care Facility, which serves in the College of Agricultural, Consumer and Environmental Sciences. Researchers in the Laboratory for Soybean Disease Research (www.soydiseases.illinois.edu) located in the University of Illinois National Soybean Research Center complete the evaluations. The bulk of the screening starts in May as soon as cultivar lists are finalized and seed packets arrive. Most of the greenhouse evaluations are completed in August, and efforts shift to evaluating cultivars for pathogen and pest resistance in field trials through September. Evaluations and analyses are completed in October before the Variety Testing Program data on yield and agronomic performance are fully compiled. Data are analyzed using Proc MIXED (SAS Institute Inc., 2008, Ver. 9.2, Cary, NC, USA). Before submission to the VIPS website in November, all the data are reviewed for accuracy and summarized. The results are merged with data from other VIPS cooperators and include data on maturity, yield, protein and oil content, soybean cyst nematode reactions, and field sudden death syndrome, and then consolidated for the VIPS website.

During the off-season, when data are published and evaluations are not in progress, many supportive activities take place, including pathogen maintenance, verification of pathogen virulence, and preparation of the strains/isolates for storage and further use. Other off-season activities include the review of resistance evaluation methods for general and specific improvements as well as training students to assist with project activities.

\section{Phytophthora Root Rot}

Phytophthora sojae is a soilborne pathogen that causes Phytophthora root rot (PRR), resulting in damping-off, root and stem rot, yellowing and wilting of lower leaves, and death of soybean plants, particularly in poorly drained soils (29). Deployment of race-specific, complete resistance genes in soybean cultivars has been used to control the disease (29). There is a gene-for-gene interaction as Rps genes confer resistance to specific races of $P$. sojae (5). At least 55 physiological races of $P$. sojae have been identified on the basis of compatible (susceptible) or incompatible (resistant) reactions after inoculation on a set of differential soybean lines possessing eight different $R p s$ genes $(4,5)$. Commonly used Rps genes in commercial cultivars include Rps $1 c, R p s l k$, and Rpsla (30). Seed companies participating in the Variety Testing Program provide resistance information about their cultivars, and identify the Rps genes in each cultivar. Partial resistance is often

Table 2. Diseases and pests evaluated for resistance in the University of Illinois (UI) Varietal Information Program for Soybeans (VIPS) from 2003 to 2011

\begin{tabular}{llc}
\hline Disease/pest & Location & Year \\
\hline Bean pod mosaic virus & Greenhouses located at UI & 2003 \\
Charcoal rot & VIPS field locations throughout Illinois & 2003,2011 \\
Frogeye leaf spot & VIPS field locations throughout Illinois & $2006-2007$ \\
Green stem disorder & VIPS field locations throughout Illinois & $2001-2011$ \\
Phytophthora root rot & Greenhouses located at UI & $2003-2011$ \\
Rhizoctonia root rot & Greenhouses located at UI & $2000-2003$ \\
Soybean rust & Fort Detrick, MD; Univ. of Florida & $2004,2006-2007$ \\
Sclerotinia stem rot & Greenhouses located at UI; VIPS field locations in region 1 (Fig. 1) & $1998-2011$ \\
Soybean aphid & Greenhouses located at UI & $2002-2011$ \\
Soybean mosaic virus & Greenhouses located at UI & $2003-2011$ \\
Stem canker (northern) & Greenhouses located at UI & 2001,2003 \\
Sudden death syndrome & Greenhouses located at UI; VIPS field locations throughout Illinois & $1998-2011$ \\
\hline
\end{tabular}

Table 3. A 1-year example (2011) of diseases and pests evaluated in the greenhouse for resistance in the University of Illinois Varietal Information Program for Soybeans

\begin{tabular}{lcccc}
\hline & & Number of & & \\
\cline { 2 - 4 } Disease/pest & Cultivars $^{\mathbf{a}}$ & Replications & Plants evaluated & Rating \\
\hline Phytophthora root rot (race 17) & 375 & $2-4$ & 6,750 & $\mathrm{R} / \mathrm{S} / \mathrm{I}$ \\
Phytophthora root rot (race 7) & 357 & $2-4$ & 6,426 & $\mathrm{R} / \mathrm{S} / \mathrm{I}$ \\
Sclerotinia stem rot & 167 & 7 & 5,845 & $1-10 \mathrm{scale}$ \\
Soybean aphid & 149 & 4 & 1,192 & $\mathrm{R} / \mathrm{S} / \mathrm{I}$ \\
Soybean mosaic virus & 323 & $2-3$ & 808 & $\mathrm{R} / \mathrm{S} / \mathrm{I}$ \\
Sudden death syndrome & 521 & 7 & 18,235 & $1-10$ scale \\
\hline
\end{tabular}

a Cultivars that were found resistant to Phytophthora sojae race 17 were again tested with Phytophthora sojae race 7. Cultivars assigned to region 1

(Fig. 1) are assessed for resistance to Sclerotinia sclerotiorum. Untreated cultivars are evaluated for resistance to soybean aphid.

${ }^{\mathrm{b}}$ Lower numbers in the rating scale refers to less disease; letters refer to: $\mathrm{R}=$ resistant, $\mathrm{S}=$ susceptible, and $\mathrm{I}=$ intermediate. 
referred to as tolerance by commercial companies and is not tested in VIPS, but field tolerance in commercial soybean cultivars with single dominant resistance does occur (7). Tolerance ratings are often reported through company websites.

Phytophthora root rot evaluation. To identify single gene resistance, the hypocotyl inoculation method is used. This is a common method for screening large populations for race-specific resistance $(5,8)$. Each year from 1998 to 2011, cultivars were evaluated for the presence of resistance genes Rpsla, Rpslc, or $R p s 1 k$ by inoculating plants with $P$. sojae race 17 or 26 on eight genes (29) (virulence formula Rps1b, Rps1d, Rps3a, Rps6, and Rps7) using the hypocotyl inoculation method (30). In 2011, race 7 (virulence formula Rps $1 a, R p s 3 a, R p s 6$, and Rps7) was used to detect the presence of Rpsla in soybean cultivars resistant to races 17 or 26. Cultivars having Rpslc or Rpslk genes survive race 7, while those with Rpsla do not.

Six seeds of each cultivar are planted in each cell of an 18-cellmulti-pot that fits in a $53 \times 36 \mathrm{~cm}$ tray (Hummert International, Earth City, MO) in a soil-less medium, Sunshine mix, LC1 (Sun Gro Horticulture Inc., Bellevue, WA). There are typically two replications per cultivar. The cultivar Sloan, which contains no known resistance gene, is included as a susceptible check for inoculations with race 17 or 26 . The cultivar Union has Rps1a and is planted as the susceptible check for evaluations with race 7 . Plants are inoculated at the unifoliolate stage of growth (7 to 10 days after sowing seeds) using an inoculum slurry to infect a wound approximately $1 \mathrm{~cm}$ long made in the stem below the cotyledonary node (Fig. 2). Plants are sprayed with water and placed in a dew chamber without light for $48 \mathrm{~h}$ at $20^{\circ} \mathrm{C}$ and $100 \%$ relative humidity. Plants are then placed in a greenhouse set at $24^{\circ} \mathrm{C}$ during the day and $20^{\circ} \mathrm{C}$ during the night with supplemental 1,000-watt high-pressure sodium and metal halide lighting with a 14-h photoperiod. The number of surviving seedlings is recorded 7 days after inoculation.

The proportion of surviving seedlings for each cultivar is calculated. Ratings are based on percentage of plants that survived where: $\mathrm{S}=$ susceptible $(20 \%$ or less survival $), \mathrm{I}=$ intermediate/segregating (21 to $79 \%$ survival, indicating the variety is segregating or is a blend), and $\mathrm{R}=$ resistant ( $80 \%$ or more survival). Additional testing is conducted if results fail to confirm the expected response of Rpsla, Rpslc, or Rpslk as reported by the companies, which are notified of any discrepancies after re-testing. VIPS evaluations also may identify the presence of unreported resistance genes, and companies are notified about these cases as well.

Over a 5-year testing period (2004 through 2008), 54\% of the cultivars tested had at least one Rps resistance gene, and only nine out of a total of 3,533 entries tested during that time reported a stacked combination of resistance genes (30). Agreement between company-reported genes and any resistance found was highest for those cultivars reported to have Rpslc (90\%) and Rpslk (83\%), followed by Rpsla (70\%) (30). In 2009, 2010, and 2011, 65, 67, and $65 \%$ of the cultivars evaluated were resistant to $P$. sojae race 17; additionally, in $2011,82 \%$ of the cultivars evaluated with $P$. sojae race 7 were resistant (Fig. 3). There were 143 cultivars (40\%) that were resistant to both races.

\section{Sclerotinia Stem Rot}

This disease, also referred to as white mold, is caused by Sclerotinia sclerotiorum, and is generally observed in the northern U.S. production areas where cooler conditions favor the growth of the

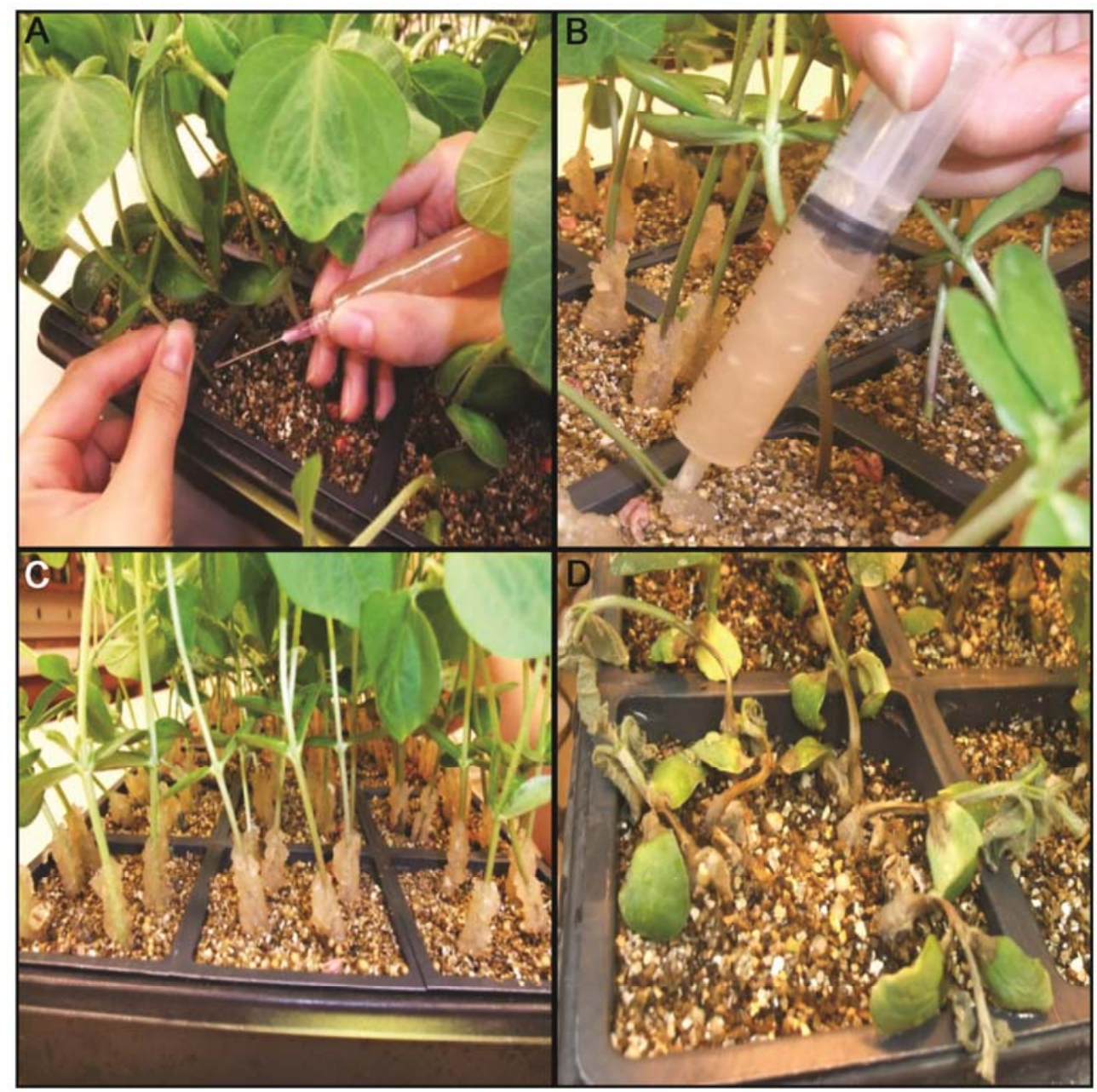

Fig. 2. Inoculation of soybean seedlings using a slurry of mycelial fragments of Phytophthora sojae. A, Hypocotyl is cut with the aid of a syringe needle. B, A slurry of inoculum is applied to the cut. C, Inoculated plants. D, Susceptible plants dying 5 to 7 days after inoculation. 
fungus (26). The disease has been reported as far south as central Illinois (12). Infected plants often collapse and die from the point of infection on the stem upward. The pathogen can be identified by the presence of a white, cottony growth on the outside of soybean stems, petioles, and pods, and as small black structures called sclerotia observed a few weeks after infection both on and in infected plant tissue (13). The sclerotia serve as overwintering structures, and a certain percentage of them will germinate each year to form apothecia, which produce ascospores that infect dehiscing flowers and re-infect plants. Sclerotia and mycelia of the pathogen sometimes contaminate seeds (12), which could be one of the distribution mechanisms for the pathogen.

Sclerotinia stem rot evaluation. Only cultivars tested in region 1 (Fig. 1) are evaluated, as environmental conditions make the disease most common in northern Illinois and less of a concern in areas further south. Evaluations are conducted in air-conditioned greenhouse rooms to mimic the natural conditions conducive to disease development. The resistance is quantitative or partial, and lesion lengths are measured to quantify the resistance.

Six seeds are planted in 15 -cm-diameter pots containing an equal mixture (1:1:1) of Sunshine Mix LC1, soil, and quartz sand. Evaluations are completed using six to eight replications with up to five plants per replication (pot). Pots are placed in a greenhouse at 25 to $30^{\circ} \mathrm{C}$ and 16 -h day length. Plants are allowed to grow in the greenhouse for 4 to 5 weeks, or until plants are large enough to be able to measure stem necrosis. Inoculum is prepared by culturing S. sclerotiorum on potato dextrose agar plates for 2 days. Plants are inoculated using the cut-stem method (23). Main stems of 4- to 5week-old plants (fifth trifoliolate leaf fully expanded) are horizontally cut with a sterile razor blade $2.5 \mathrm{~cm}$ above either the fourth or fifth node. The base of a $200-\mu l$ pipette tip is used to take a plug of inoculum from the actively growing outer edge of the culture, and the pipette tip with mycelial plug inside is placed on the cut stem (Fig. 4A and B). Inoculated plants are incubated in a mist chamber at near $100 \%$ relative humidity for $24 \mathrm{~h}$. The chamber is maintained at $20 \pm 1{ }^{\circ} \mathrm{C}$ and covered with black mesh cloth (80\% light reduction). Inoculated plants are then transferred to an adjacent room at $22 \pm 2{ }^{\circ} \mathrm{C}$, and disease symptoms are allowed to develop which include stem die back often associated with sclerotia formation on the colonized stem (Fig. 4C and D). At 12 days after inoculation, lesion length $(\mathrm{cm})$ on the main stem is measured. Data are normalized to a 1 to 10 scale for grower use on the VIPS website.
For Sclerotinia stem rot evaluations, 179, 183, and 167 cultivars were evaluated in 2009, 2010, and 2011, respectively (Fig. 5). The average disease severity over the 3 years for the partially resistant check, DSR-2400, was 4.3 (normalized on 1 to 10 scale) and 8.2 for Fairbault, the susceptible check. In 2009, the mean severity rating for the trial was 5.4, with 40 and 17 cultivars being one and two standard deviations below the trial mean. In 2010, the mean severity rating for the trial was 6.7 , with 56,6 , and 1 cultivar being one, two, and four standard deviations below the trial mean. In 2011 , the mean severity rating for the trial was 6.4 , with 45,8 , and 2 cultivars being one, two, and three standard deviations below the trial mean.

\section{Soybean Aphid}

The soybean aphid, Aphis glycines, is the primary aphid species known to colonize soybean in North America (17). In Illinois, the soybean aphid was first reported in 2001 (9). The soybean aphid became established across most of the main soybean-growing belt in both Canada and the United States within a year or two after the 2001 report (32). One of the key factors aiding its establishment in North America was the large pool of Rhamnus cathartica L. (common buckthorn) present on the continent, which serves as primary host for sexual reproduction and where the aphid overwinters as eggs. High soybean aphid populations reduce soybean yield directly when their feeding causes stunting, leaf distortion, and reduce pod set (18). Furthermore, soybean aphids have the ability to transmit plant viruses to soybean such as Soybean mosaic virus (9). Honeydew excreted by soybean aphids onto leaves leads to the development of sooty mold, which inhibits photosynthesis (9).

Prior to 2009, all commercial and pre-commercial soybean cultivars tested in VIPS were susceptible to the soybean aphid. Resistance to the soybean aphid was discovered in older soybean cultivars, PI 548663 (cultivar Dowling) and PI 548657 (cultivar Jackson), that are ancestors of current cultivars adapted to the southern United States (18). Further research identified new sources of resistance, and resistance genes were mapped. A recent review showed that there are currently six named soybean aphid resistance genes (15). Some of these genes are now available to growers in commercial soybean cultivars.

Soybean aphid evaluation. Resistance to aphid infestation is determined in aphid feeding preference experiments called choice tests (18). In 2004, we observed that cultivars with any type of chemical seed treatments were less likely to undergo aphid feeding

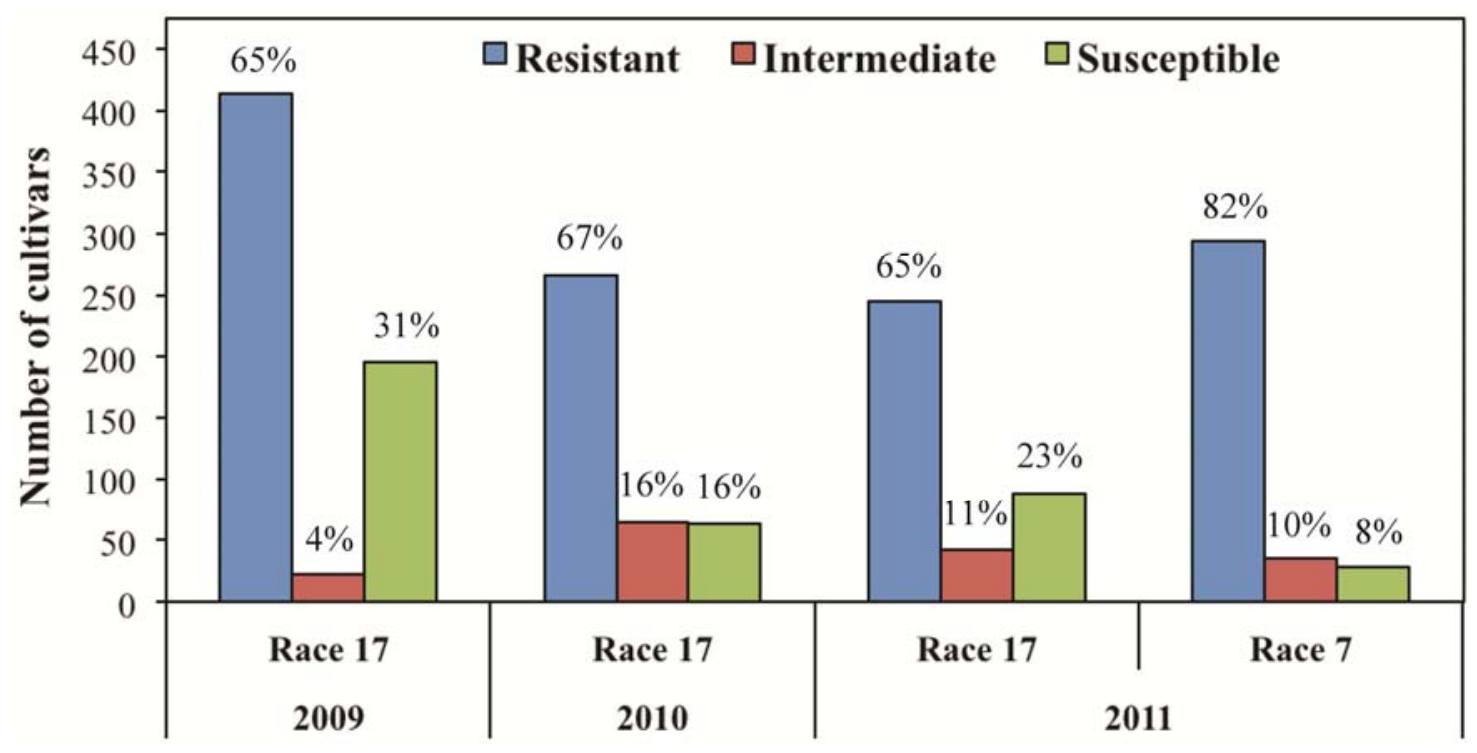

Fig. 3. Frequency distribution of responses of 1,760 cultivars to Phytophthora sojae race 17 from 2009 to 2011 and to race 7 in 2011 . Ratings were based on percentage of plants that survived where: resistant $=80 \%$ or more survival; intermediate $=21$ to $79 \%$ survival, indicating the cultivar is segregating or is a blend; and susceptible $=20 \%$ or less survival. In 2011, cultivars that were found resistant to $P$. sojae race 17 were again tested with $P$. sojae race 7 . 
than cultivars without seed treatments. Since that time, to avoid insecticidal seed treatments affecting test results, only cultivars without seed treatments have been evaluated, and companies are requested to provide untreated seed specifically for this evaluation. The resistant checks used in the test are Dowling, LD05-16657, LD08-12592, and PI 437696; the susceptible check is Williams 82.
The test is conducted in an air-conditioned, insecticide-free greenhouse maintained at 22 to $25^{\circ} \mathrm{C}$ with supplemental illumination. The test consists of four replications with two plants per replication. Leaves from Williams 82 plants infested with a single clone of aphid biotype 1 (no known genes for virulence) are placed on 1week-old newly emerged seedlings grown in Sunshine mix LC1 in plastic multi-pots.

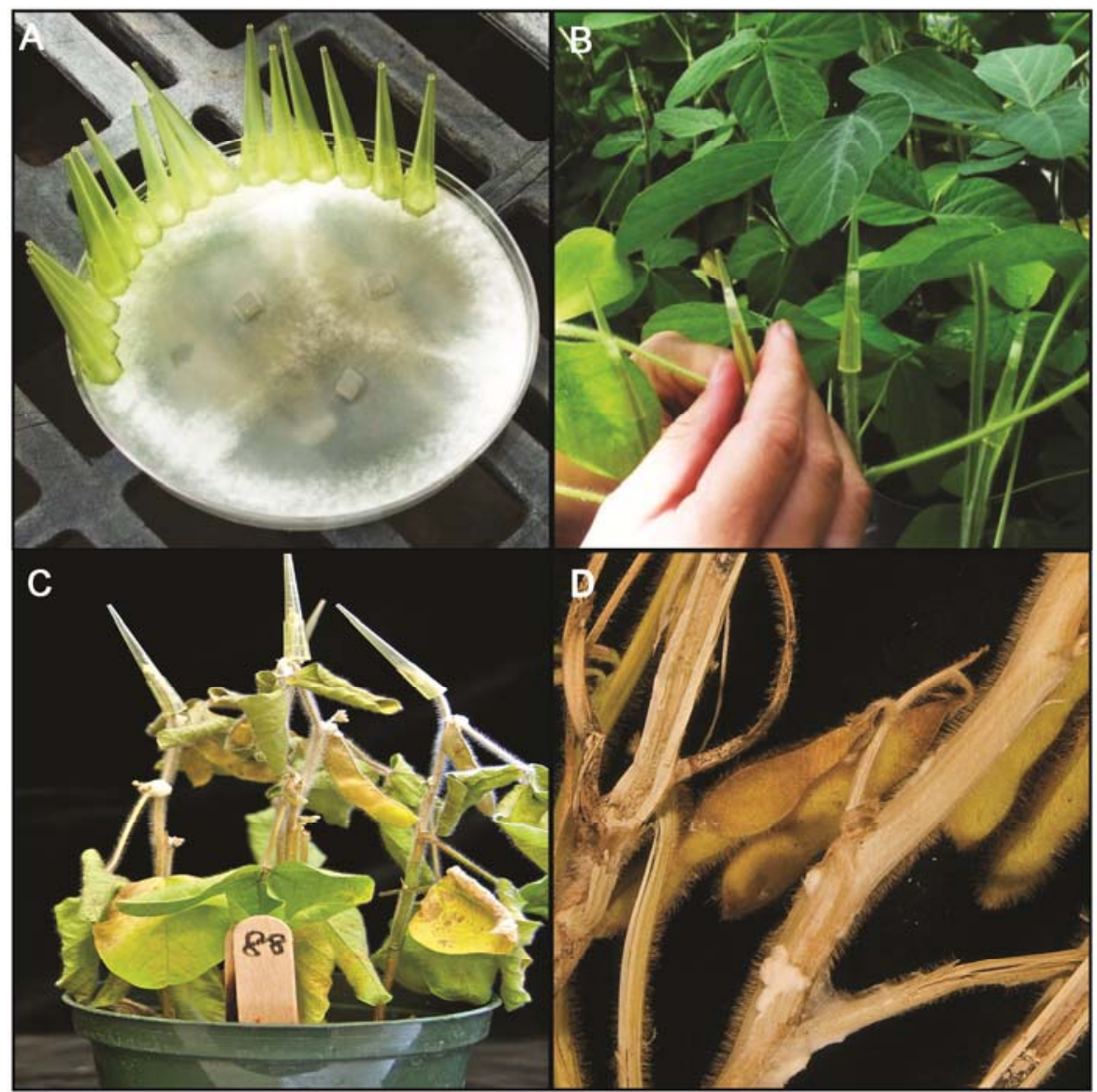

Fig. 4. A, Pipette tips used to capture a Sclerotinia sclerotiorum mycelial plug from a 2-day-old culture that was started with three agar plugs. B, Inoculation of cut stems of soybean plants using pipette tips. C, Inoculated plants showing chlorosis of leaves and bleached lesions on stem. D, Colonized soybean stem showing fungal sclerotia in the stem and developing on the stem.

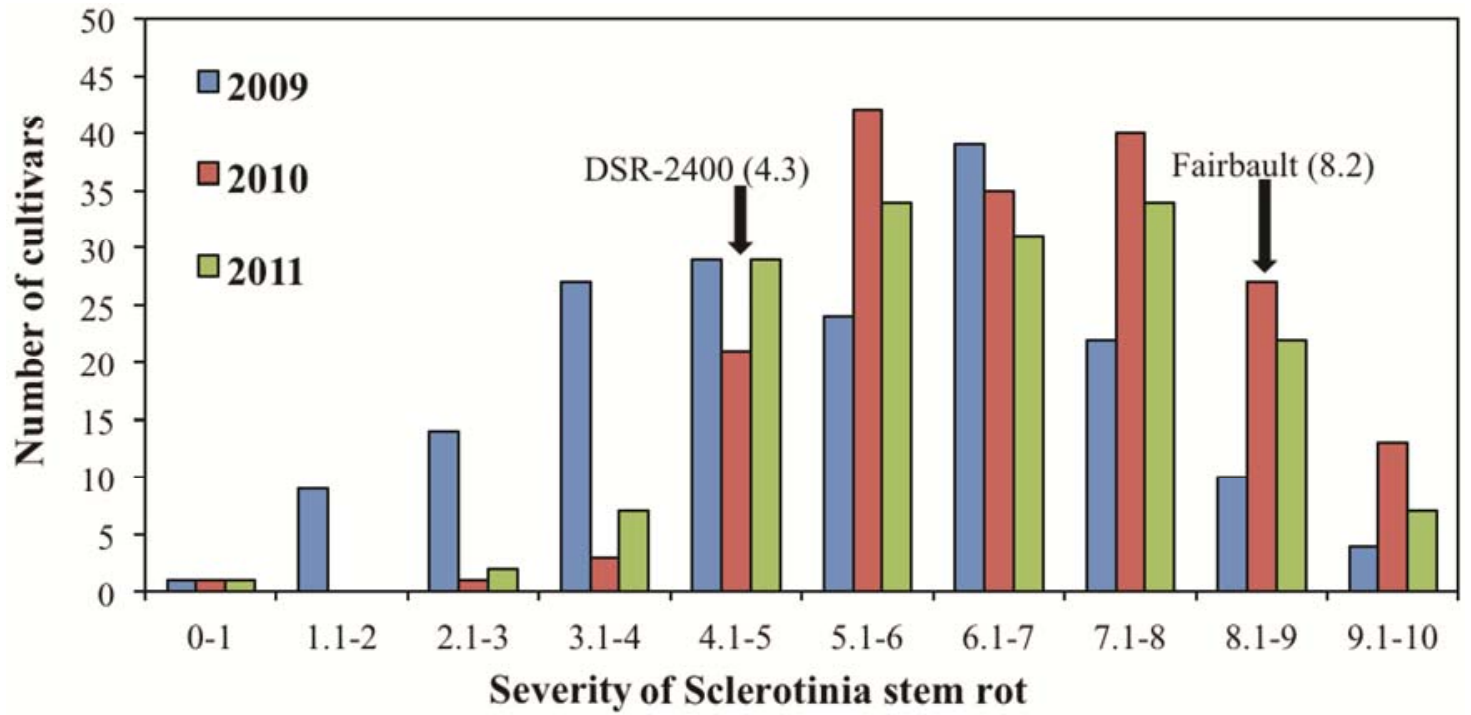

Fig. 5. Frequency distribution of lesion length of 529 soybean cultivars evaluated for responses to Sclerotinia sclerotiorum in 2009, 2010, and 2011. Lesion length (cm) on the main stem was measured 12 to 14 days after inoculation for each plant, and data were normalized to a 1 to 10 scale. DSR-2400 and Fairbault were used as resistant and susceptible checks, respectively. Normalized mean values of checks were averaged for 2009 to 2011 to compare the cultivars. 
The level of aphid colonization is evaluated at 14 and 20 days after infestation (Fig. 6). Scores between 0 and 5 are assigned based on the presence of aphids and leaf damage, where $0=$ no aphids and no damage, $1=$ few transitory aphids, no damage; $2=$ small scattered colonies without plant damage; $3=$ dense colonies, mild leaf distortion or discoloration; $4=$ dense colonies, severe leaf distortion, discoloration, and stunting; and $5=$ plants dead (18). Cultivars with a score lower than 3 are retested five to six times to detect misses. For presentation to the VIPS website, ratings of 0 to 2 are considered resistant, a rating of 3 is intermediate, and ratings of 4 and 5 are susceptible.

Despite reports that resistance genes are being incorporated into commercial germplasm, the results of the aphid resistance evaluations for 2004 through 2011 have shown almost all cultivars to be susceptible. In 2009, only 2 of 41 cultivars were resistant. No cultivar was found resistant in 2010 and 2011. Because only cultivars without seed treatments are evaluated, there may be undetected resistance in cultivars only available with seed treatments.

\section{Soybean Mosaic}

Soybean mosaic virus (SMV) symptoms may vary with host genotype, virus strain, plant age at infection, and environmental conditions, but most infected soybean plants are stunted, have leaf mottling, produce fewer pods, and have seeds that are often mottled (Fig. 7) (19). Trifoliolate leaves have a mosaic of light and dark green areas that may later become raised or blistered, particu- larly along the main veins. SMV is transmitted through seed (2), and by aphids (3).

A significant number of commercial cultivars are known to have SMV resistance $(33,34)$. Strains of SMV, G1 through G7, have been identified based upon reactions to a set of differential soybean lines $(1,19)$. At least three naturally occurring independent loci, designated $R s v 1, R s v 3$, and $R s v 4$, have been identified for resistance to SMV and mapped (28). The Rsvl locus provides resistance to SMV strain G1 (22).

Soybean mosaic evaluations. Seeds are planted in a soil-less mix (Sunshine Mix LC1) in 96-well inserts in plastic trays, one plant per line. SMV strain G1 was chosen for evaluation of VIPS genotypes because it was the most common strain found in an international seed collection (1). Inoculum is prepared by grinding infected Williams 82 leaves with sterilized pestles and mortars in chilled $0.025 \mathrm{M} \mathrm{KPO}_{4}$ buffer, $\mathrm{pH} 7.1$, plus $0.01 \mathrm{M}$ sodium sulfite. Pestles are used to apply inoculum to Carborundum-dusted leaf surfaces. Plants are inoculated with SMV-G1 7 to 10 days after planting at growth stage V1. Two to three weeks after inoculation, trifoliate leaves are examined for virus symptoms. Leaf samples from individual plants are tested for the presence of SMV using a tissue blot immunoassay or dot blot $(24,31)$. All cultivars showing resistant or mixed reactions are retested in a replicated test with Williams 82 and Peking used as the susceptible and resistant checks, respectively. Results are presented on the VIPS website as resistant (no SMV detected), susceptible (SMV detected), or mixed
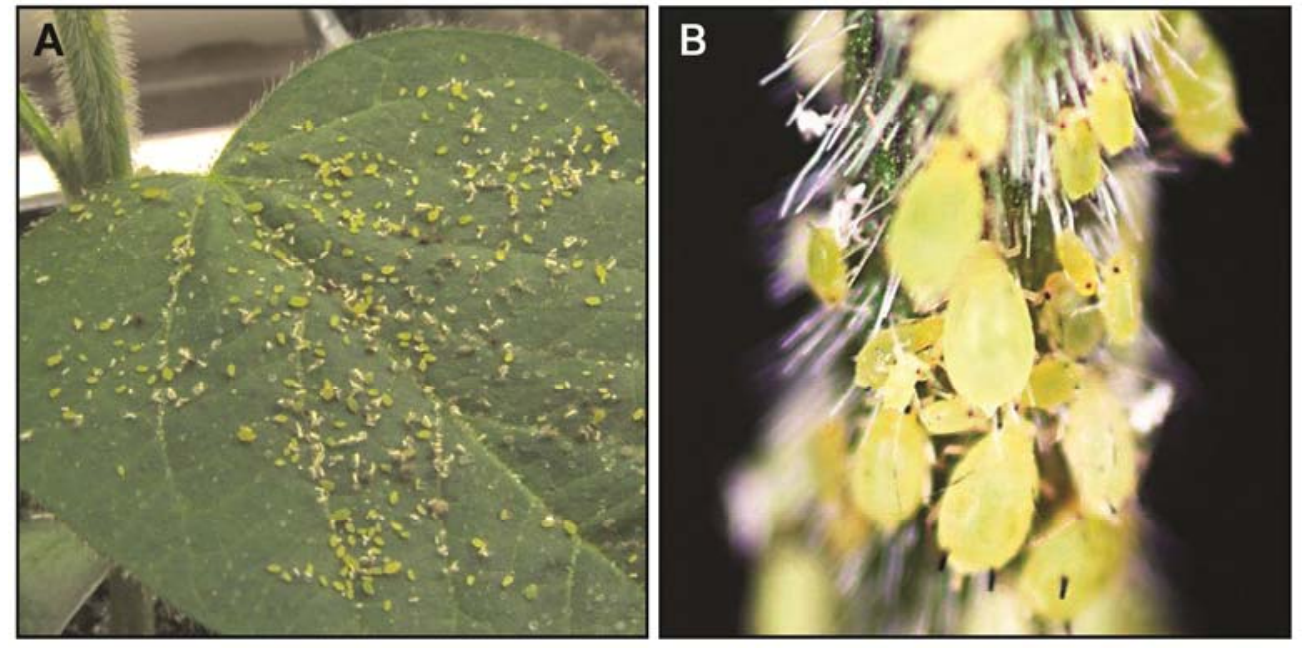

Fig. 6. Soybean aphids feeding on A, leaves, and B, the stem of a susceptible soybean cultivar.

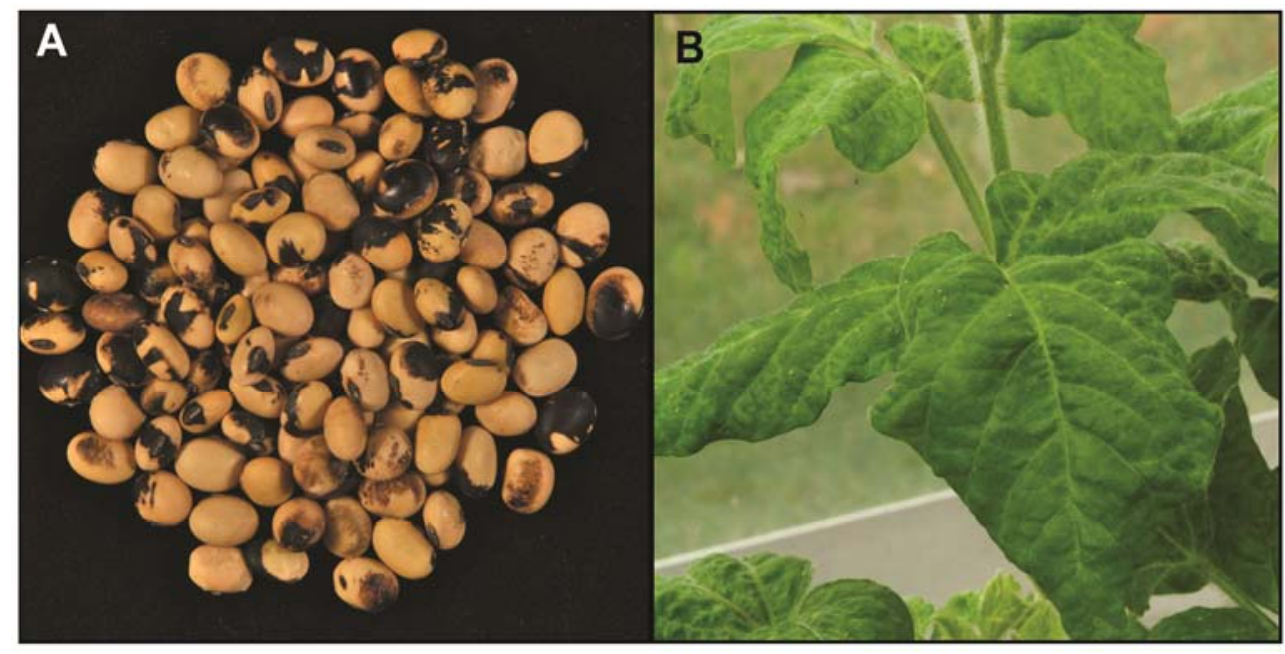

Fig. 7. Soybean mosaic virus infection causing A, discolored seeds, and B, puckered and curled leaves. 
reaction. A total of 374,392 , and 323 cultivars were evaluated for SMV resistance in 2009, 2010, and 2011, with 6, 6, and 9 cultivars in those years, respectively, found to have resistance.

\section{Sudden Death Syndrome}

Sudden death syndrome (SDS), caused by Fusarium virguliforme (Fig. 8A), is a mid- to late-season disease with distinctive foliar symptoms that commonly occur in high-yield environments (27). Yield losses from SDS are dependent on disease onset and severity, ranging from slight to nearly $100 \%$. In the early reproductive growth stages, leaves show interveinal chlorosis and necrosis (Fig. 8B). The root mass of SDS-affected plants is reduced, and roots are discolored.

Soybean resistance to $F$. virguliforme is not complete. Differences have been reported in the level of resistance among soybean cultivars (25) and soybean plant introductions (11). There have been many reports on mapping quantitative trait loci (QTL) associated with resistance. One report mapped and confirmed a new SDS resistance QTL on linkage group D2 from the soybean genotypes PI 567374 and Ripley (6). Many companies provide SDS scores for their cultivars.
Sudden death syndrome evaluation. All cultivars are tested for their SDS reaction in a seedling test. The greenhouse SDS test is resource intensive, requiring one full day for five employees to plant a complete replication and 5 to 8 replications to detect significant differences, but all cultivars are evaluated with consistent disease pressure and uniform conditions. In this way, all cultivars can be compared to one another without the influence of maturity or the genetic by environmental interactions found in field trials.

Soybean cultivars are evaluated in the greenhouse using a modified layer method (11). An isolate of $F$. virguliforme, Mont-1 (originating from Monticello, IL), is maintained in the dark at $23^{\circ} \mathrm{C}$ on potato dextrose agar for 14 to 21 days. The fungus is increased on sorghum seeds that are soaked overnight in plastic trays and autoclaved on two successive days in bags. Autoclaved sorghum seeds are infested with fungal mycelium grown in petri dishes on potato dextrose agar cut into approximately $1-\mathrm{cm}$ squares, heat-sealed, and incubated at room temperature for 2 weeks. Inoculum is air-dried at room temperature for 24 to 48 hours and stored in paper bags in a cold room at $5^{\circ} \mathrm{C}$.

To prepare experimental flats, a layer of paper towel is set at the

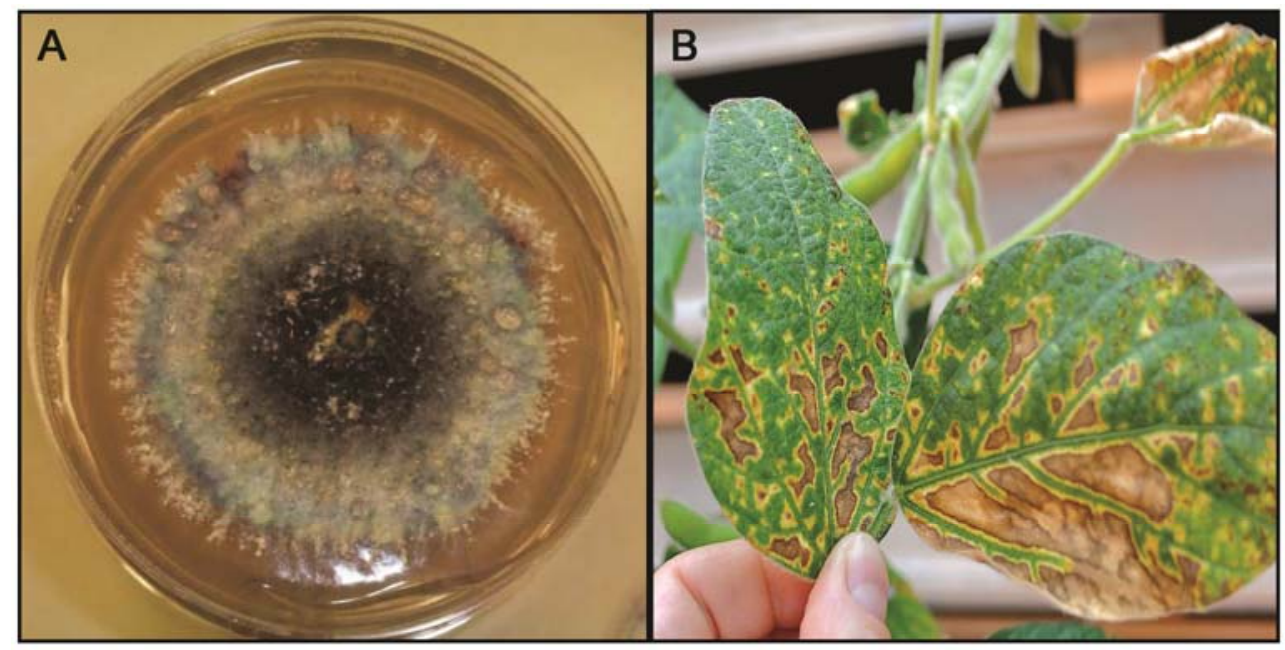

Fig. 8. A, Culture of Fusarium virguliforme on potato dextrose agar. B, Soybean leaves showing interveinal chlorosis and necrosis.

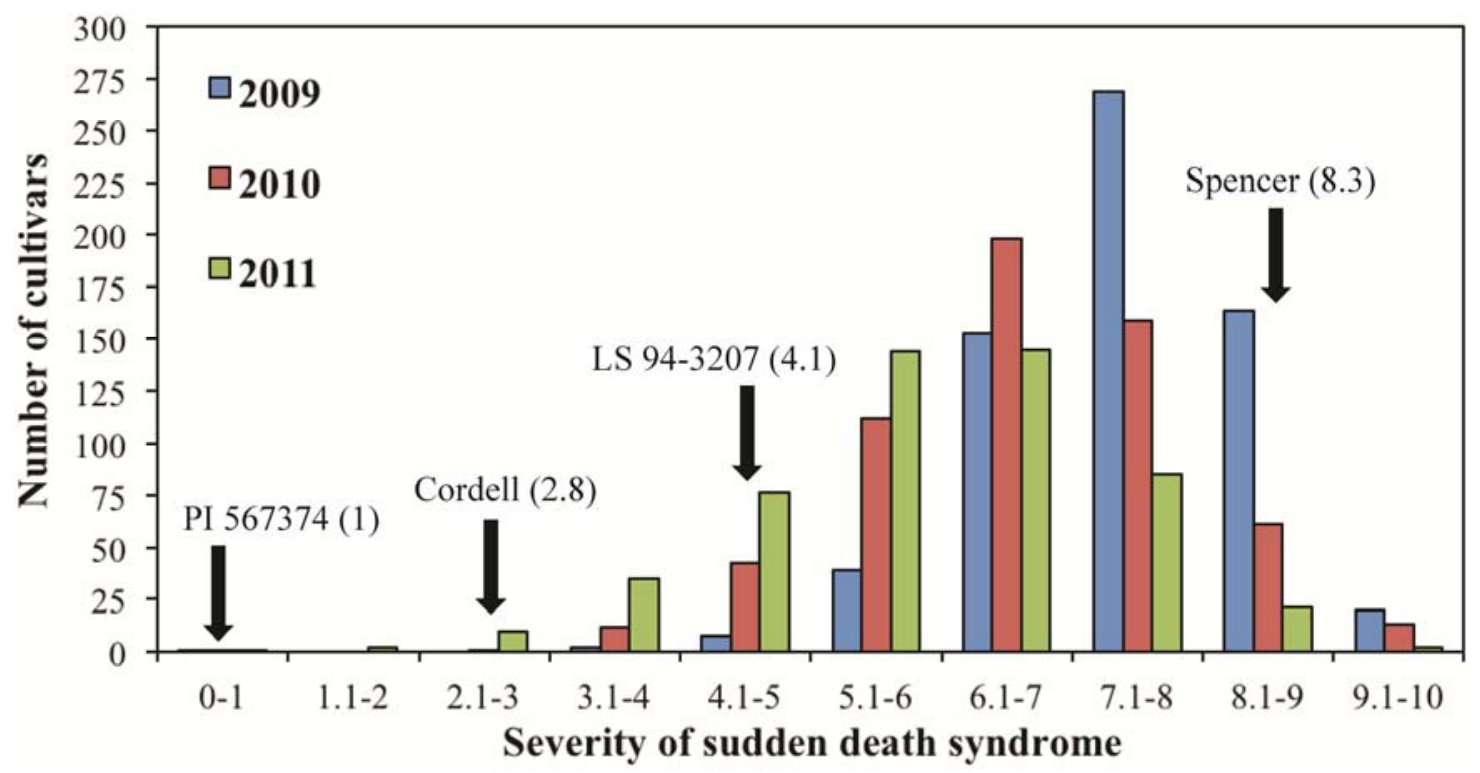

Fig. 9. Frequency distribution of 1,776 cultivars evaluated for responses to Fusarium virguliforme in 2009 to 2011. Plants were evaluated 21 to 28 days after planting for leaf scorch severity using a scale from 1 (no symptoms) to 8 (dead plant), and data were normalized on a 1 to 10 scale. PI 567374 was used as a resistant check; Cordell and LS 94-3207 as moderately resistant checks; and Spencer as the susceptible check. Normalized mean values of checks were averaged for 2009 to 2011 to compare the cultivars. 
bottom of $10 \times 36 \times 51 \mathrm{~cm}$ dyna-flats to prevent soil loss. Layers of soil mix and inoculum mix are measured and added to the flat. First, 3,200 ml of soil mix (1:1:1 Sunshine Mix LC1: soil: quartz sand) is added to the tray and leveled. A second layer of $1,600 \mathrm{ml}$ of premixed inoculum and soil mix (336 $\mathrm{ml}$ infested sorghum and $1,264 \mathrm{ml} \mathrm{1:1:1} \mathrm{soil} \mathrm{mix)} \mathrm{is} \mathrm{added} \mathrm{on} \mathrm{top} \mathrm{of} \mathrm{the} \mathrm{first} \mathrm{layer} \mathrm{and} \mathrm{lev-}$ eled. The third layer of $3,200 \mathrm{ml}$ of soil mix is then added and leveled to complete the base. A template is used to make eight uniform furrows, approximately 0.5 to $1 \mathrm{~cm}$ deep and $1 \mathrm{~cm}$ wide in the soil. Each furrow is then planted with three plots of five seeds, for a total of 24 plots per flat, and another 1,600 ml 1:1:1 soil mix layer is added. Four checks are included in each flat: Spencer (susceptible), Cordell and LS94-3207 (moderately resistant), and PI567374 (partially resistant). Plants are evaluated 21 to 28 days after planting for leaf scorch severity. SDS reaction is noted using a scale from 1 (no symptoms) to 8 (dead plant). To simplify the interpretation of results, data are normalized on a 1 to 10 scale for grower use on the VIPS website.

In evaluations during 2009 to $2011,17 \%$ of $656,4 \%$ of 599 , and $19 \%$ of 521 cultivars were considered partially resistant, respectively. In 2009, the cultivar mean rating was 7.5 (normalized on a 1 to 10 scale), with $143,36,8,2$, and 1 cultivar falling one, two, three, four, and seven standard deviations below the trial mean, respectively (Fig. 9). In 2010, the cultivar mean rating was 6.7, with $130,32,7$, and 1 cultivar falling one, two, three, and five standard deviations below the trial mean, respectively (Fig. 9). In 2011, the cultivar mean rating was 5.9, with $105,34,5$, and 1 cultivar falling one, two, three, and four standard deviations below the trial mean, respectively (Fig. 9).

\section{Disease and Pest Data from Field Trials}

From 2003 to 2011, data have been collected on brown stem rot, charcoal rot, frogeye leaf spot, green stem disorder, Sclerotinia stem rot, and sudden death syndrome at locations and in years when the diseases occurred.

Locations are monitored to decide which diseases and pests to evaluate. Environmental factors, particularly weather and the rate at which cultivars mature, influence disease development. Commonly, disease occurrence is narrowly limited to a specific maturity group and/or a particular location. If a whole experiment cannot be analyzed, data will not be collected. Additionally, if only

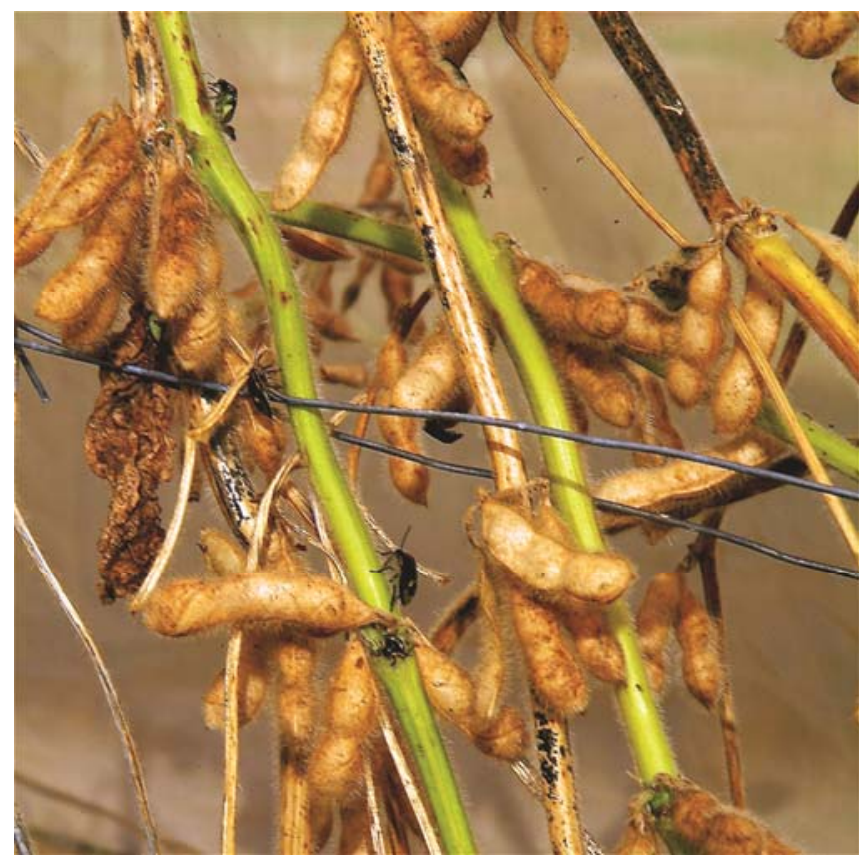

Fig. 10. Comparison of normal maturing soybean stems and stems with green stem disorder. limited experiments within a location have disease data, the data may not be reported on the website.

Soybean cultivars have a short market life. On average, 54\% of the cultivars submitted to VIPS each year are new (30). This reduces the likelihood that data can be collected on the same cultivar for multiple years. Data from multiple locations and regions provides more value. Priority for data collection and analysis is given to diseases or pests that are economically important, widespread, and likely to provide information from multiple trials and multiple locations.

Green stem disorder (GSD) has been noted in VIPS evaluation plots consistently since 2003 and has varied in incidence from one location to another and from year to year (16). Green stem disorder is a common condition in which stems of soybean plants remain green well past the point of physiological maturity as indicated by pod ripening and seed maturation (21). The tough green stems are more difficult for combines to cut and thresh (Fig. 10).

Field evaluation of GSD. Occurrences of GSD in the Illinois Variety Testing Program field locations are recorded near harvest maturity as percent green stem per plot. Like other field notes collected at the Variety Testing locations, GSD data are analyzed with SAS software. This allows for comparisons among cultivars of similar maturity and herbicide resistance type (conventional and glyphosate tolerant) at each location or region. GSD data are converted to a 0 to 5 scale using arcsine transformation where $0=$ no green stem, $1=1$ to $10 \%$ green stem, $2=11$ to $35 \%$ green stem, 3 $=36$ to $65 \%$ green stem, $4=66$ to $90 \%$ green stem, and $5=91$ to $100 \%$ green stem. From 2009 to 2011, a total of 1,509 entries were evaluated at eight field locations throughout Illinois. These ratings were recorded in 10,094 plots and converted to percent. The range of incidence with the mean in parentheses of GSD was 0-(10)-95\% in 2009, $0-(11)-95 \%$ in 2010, and 0-(2)-60\% in 2011. GSD has varied in incidence among genotypes, locations, and years.

\section{Other Disease Evaluations}

Soybean cultivars in VIPS have been evaluated for response to diseases not described in detail here (Table 2). This includes evaluations for Bean pod mottle virus (BPMV), which causes similar symptoms to SMV and requires a similar inoculation technique (20). We did not find any resistance in our evaluations and discontinued testing. Evaluations for VIPS cultivars in the field have been completed for brown stem rot, frogeye leaf spot, Sclerotinia stem rot, and SDS but are not reported here due to the lack of uniform distribution of disease occurrence. We also evaluated cultivars in VIPS for resistance to soybean rust in both field and greenhouse conditions with no resistance found in any commercial cultivars.

\section{Summary}

The information generated through the evaluation of soybean cultivars entered into VIPS provides an independent, objective, and unbiased assessment of hundreds of soybean cultivars in maturity groups representing those used or targeted for use in the majority of soybean acreage planted in the United States. Although seed providers characterize some disease and pest reactions for their products, inconsistencies among company information persist and include variation in diseases and pests evaluated, methods of evaluation, and reporting of results. Our service enables growers to effectively compare disease and pest resistance traits for soybean cultivars from multiple companies and make more informed selection of cultivars. In areas where specific pests or diseases are common, such information helps producers make crop management decisions by identifying cultivars with traits of interest.

In addition to helping soybean growers make educated decisions about cultivar selection, VIPS benefits commercial seed companies. Seed companies confirm and/or supplement their product information with data reported in VIPS. This allows them to compare their cultivars with hundreds of competitive cultivars may otherwise be prohibitive for companies to accomplish. 
The VIPS cultivar list provides an annual representation of cultivars grown in the Midwest. The relatively short product life of most commercial cultivars as well as the consistent quality of data coming from the program make the timely and independent information from VIPS valuable to the many stakeholders in Illinois agriculture.

\section{Acknowledgments}

We acknowledge the Illinois Soybean Association's long-time support of this research. We thank the National Soybean Research Laboratory staff, and Linda Kull and Linda Lee for coordinating VIPS. We thank Ralph W. Esgar and Brian Henry for compiling cultivar lists, distributing seeds, and managing the Variety Testing locations. We thank Reid Federick (Frederick, MO) and James Marois (Quincy, FL) for providing facilities to evaluate soybean rust. We thank Theresa Herman for her review and editorial comments. Finally, our thanks go to the good-natured assistance of 22 undergraduate students employed specifically for this effort since 2003

\section{Literature Cited}

1. Cho, E. K., and Goodman, R. M. 1979. Strains of soybean mosaic virus: Classification based on virulence in resistant soybean cultivars. Phytopathology 69:467-470.

2. Domier, L. L., Hobbs, H. A., McCoppin, N. K., Bowen, C. R., Steinlage, T. A., Chang, S., Wang, Y., and Hartman, G. L. 2011. Multiple loci condition seed transmission of Soybean mosaic virus (SMV) and SMV-induced seed coat mottling in soybean. Phytopathology 101:750-756.

3. Domier, L. L., Latorre, I. J., Steinlage, T. A., McCoppin, N., and Hartman, G. L. 2003. Variability and transmission of Aphis glycines of North American and Asian soybean mosaic virus isolates. Arch. Virol. 148:19251941.

4. Dorrance, A. E., Jia, H., and Abney, T. S. 2004. Evaluation of soybean differentials for their interaction with Phytophthora sojae. Plant Health Progess doi:10.1094/PHP-2004-0309-01-RS

5. Dorrance, A. E., and St. Martin, S. 2000. Phytophthora sojae: Is it time for a new approach? APSnet Features. Online. doi: 10.1094/APSnetFeature2000-0700B

6. Farias Neto, A. F., Hashmi, R., Schmidt, M., Carlson, S. R., Hartman, G. L. Li, S., Nelson, R. L., and Diers, B. W. 2007. Mapping and confirmation of a new sudden death syndrome resistance QTL on linkage group D2 from the soybean genotypes PI 567374 and 'Ripley'. Mol. Plant Breed. 20:5362.

7. Ferro, C. R., Hill, C. B., Miles, M. R., and Hartman, G. L. 2006. Evaluation of soybean cultivars with Rps $1 k$ gene for partial resistance or field tolerance to Phytophthora sojae. Crop Sci. 46:2427-2436.

8. Haas, J. H., and Buzzell, R. I. 1976. New races 5 and 6 of Phytophthora megasperma var. sojae and differential reactions of soybean cultivars for races 1 to 6 . Phytopathology 6:1361-1362.

9. Hartman, G. L., Domier, L. L., Wax, L. M., Helm, C. G., Onstad, D. W., Shaw, J. T., Solter, L. F., Voegtlin, D. J., D’Arcy, C. J., Gray, M. E., Steffey, K. L., Isard, S. A., and Orwick, P. L. 2001. Occurrence and distribution of Aphis glycines on soybeans in Illinois in 2000 and its potential control. Plant Health Progess doi:10.1094/PHP-2001-0205-01-HN

10. Hartman, G. L., and Hill, C. B. 2010. Diseases of soybean and their

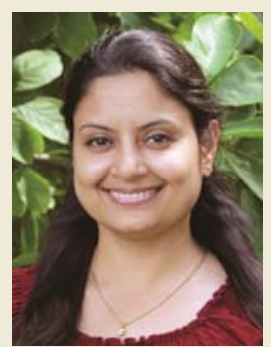

Shilpi Chawla

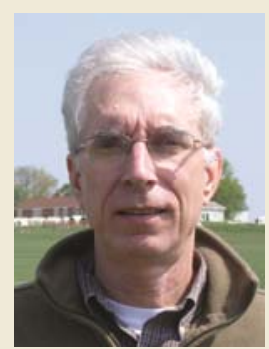

Charles R. Bowen

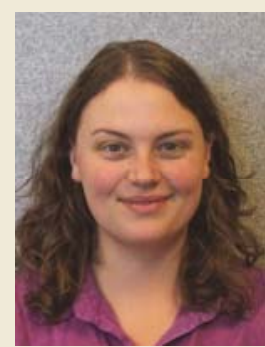

Tara L. Slaminko

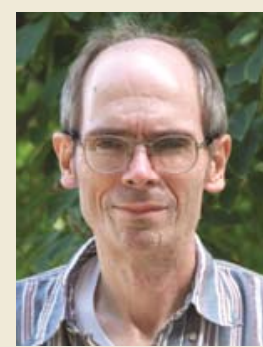

Houston A.

Hobbs

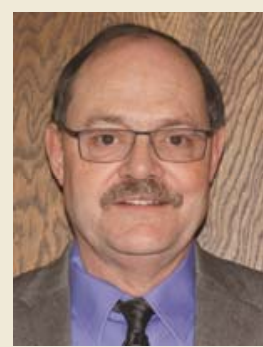

Glen L. Hartman
Dr. Chawla is a postdoctoral research associate in the Department of Crop Sciences at University of Illinois. She earned a B.S. in agriculture and an M.S. in plant pathology from the Gobind Ballabh Pant University of Agriculture and Technology, India. Her Ph.D. in plant pathology is from the Texas Tech University, USA, where her research focused on population dynamics of soilborne pathogens of cotton. Currently, her research focuses on evaluating commercial soybean cultivars for resistance to economically important pathogens and pests for the Varietal Information Program for Soybeans.

Dr. Bowen, after earning M.S. and Ph.D. degrees in plant breeding and genetics at Kansas State University, was employed as station manager and maize breeder by BioTechnica International and Limagrain Genetics (AgReliant Genetics). While with Limagrain, he also managed the U.S inbred and hybrid disease evaluation trials. As a visiting senior research specialist in the Department of Crop Sciences, he managed the disease and pest evaluations described in this paper from 2003 through 2007. He focused efforts on diseases and techniques appropriate for the entire entry list and emphasized use of the Variety Testing field plots. He is currently employed by the USDA ARS as a biological science technician, where he continues to work for the Laboratory for Soybean Disease Research located at the University of Illinois Urbana-Champaign.

Ms. Slaminko earned her B.S. and M.S. at the University of Illinois at Urbana-Champaign while working in the Laboratory for Soybean Disease Research in the Department of Crop Sciences. After completing her M.S. in plant pathology, she managed the disease and pest evaluations for VIPS from 2008 to 2011 . She currently works as a soy- bean breeder for Pioneer Hi-Bred International in Ivesdale, IL.

Dr. Hobbs is a research specialist in the Department of Crop Sciences at the University of Illinois. He earned a B.S. in botany and bacteriology from the University of Arkansas, an M.S. from the University of Arkansas in plant pathology, and a Ph.D. from the University of Georgia in plant pathology. Dr. Hobbs' work in the soybean disease research programs of Dr. Domier and Dr. Hartman includes screening for resistance in soybean to viruses occurring in Illinois, surveys of viruses in Illinois soybean fields, studies of insect vectors and virus transmission through seed, and identification and characterization of viruses infecting soybean fungal pathogens.

Dr. Hartman is a research plant pathologist with USDA Agricultural Research Service and a professor of plant pathology in the Department of Crop Sciences, University of Illinois. He earned a B.S. degree in plant health technology and M.S. and Ph.D. degrees in plant pathology from the University of Illinois. He started his post Ph.D. career in 1988 and worked for 5 years at two international centers as the leader of the cowpea pathology program and as head plant pathologist responsible for host resistance research on bacterial and fungal diseases of vegetables including soybean. Since 1993, his research focus has been on variability and biology of soybean pathogens, epidemiology of soybean diseases, the nature and genetics of host plant resistance, and soybean disease management located at the University of Illinois. His publications include more than 200 refereed journal articles, 38 papers in proceedings, seven book sections, six book chapters, three edited books, two edited proceedings, one book, and two patents. 
management. Pages 276-299 in: The Soybean. G. Singh, ed. CABI, Wallingford, UK

11. Hartman, G. L., Huang, Y. H., Nelson, R. L., and Noel, G. R. 1997. Germplasm evaluation of Glycine max for resistance to Fusarium solani, the causal organism of sudden death syndrome. Plant Dis. 81:515-518.

12. Hartman, G. L., Kull, L., and Huang, Y. H. 1998. Occurrence of Sclerotinia sclerotiorum in soybean fields in East-Central Illinois and enumeration of inocula in soybean seed lots. Plant Dis. 82:560-564.

13. Hartman, G. L., Sinclair, J. B., and Rupe, J. C., eds. 1999. Compendium of Soybean Diseases. American Phytopathological Society, St. Paul, MN.

14. Hartman, G. L., West, E., and Herman, T. 2011. Crops that feed the world 2. Soybean-worldwide production, use, and constraints caused by pathogens and pests. Food Security 3:5-17.

15. Hill, C. B., Chirumamilla, A., and Hartman, G. L. 2012. Resistance and virulence in the soybean-Aphis glycines interaction. Euphytica DOI $10.1007 / \mathrm{s} 10681-012-0695-\mathrm{z}$

16. Hill, C. B., Hartman, G. L., Esgar, R., and Hobbs, H. A. 2006. Field evaluation of green stem disorder in soybean cultivars. Crop Sci. 46:879885.

17. Hill, C. B., Li, Y., and Hartman, G. L. 2004. Resistance of Glycine species and various cultivated legumes to the soybean aphid (Homoptera: Aphididae). J. Econ. Entomol. 97:1071-1077.

18. Hill, C. B., Li, Y., and Hartman, G. L. 2004. Resistance to the soybean aphid in soybean germplasm. Crop Sci. 44:98-106.

19. Hill, J. H. 1999. Soybean mosaic. In: Compendium of Soybean Diseases, 4th ed. G. L. Hartman, J. B. Sinclair, and J. C. Rupe, eds. American Phytopathology Society, St. Paul, MN.

20. Hobbs, H. A., Hartman, G. L., Wang, Y., Hill, C. B., Bernard, R. L., Pedersen, W. L., and Domier, L. L. 2003. Occurrence of seed coat mottling in soybean plants inoculated with Bean pod mottle virus and Soybean mosaic virus. Plant Dis. 87:1333-1336.

21. Hobbs, H. A., Hill, C. B., Grau, C. R., Koval, N. C., Wang, Y., Pedersen, W. L., Domier, L. L., and Hartman, G. L. 2006. Green stem disorder of soybean. Plant Dis. 90:513-518.

22. Kiihl, R. A. S., and Hartwig, E. E. 1979. Inheritance of reaction to soybean mosaic virus in soybean. Crop Sci. 19:372-375.

23. Kull, L. S., Vuong, T. D., Powers, K. S., Eskridge, K. M., Steadman, J. R., and Hartman, G. L. 2003. Evaluation of three resistance screening methods using six Sclerotinia sclerotiorum isolates and three entries of each soybean and dry bean. Plant Dis. 87:1471-1476.

24. Lin, N. S., Hsu, Y. H., and Hsu, H. T. 1990. Immunological detection of plant viruses and a mycoplasmalike organism by direct tissue blotting on nitrocellulose membranes. Phytopathology 80:824-828.

25. Mueller, D. S., Nelson, R. L., Hartman, G. L., and Pedersen, W. L. 2003. Response of commercially developed cultivars and ancestral soybean lines to Fusarium solani $\mathrm{f}$. sp. glycines. Plant Dis. 87:827-831.

26. Nelson, B., Helms, T., and Kural, I. 1991. Effects of temperature and pathogen isolate on laboratory screening of soybean for resistance to Sclerotinia sclerotiorum. Can. J. Plant Sci. 71:347-352.

27. Rupe, J. C., and Hartman, G. L. 1999. Sudden Death Syndrome. Pages 3739 in: Compendium of Soybean Diseases. G. L. Hartman, J. B. Sinclair, and J. C. Rupe, eds. American Phytopathological Society, St. Paul, MN.

28. Saghai Maroof, M. A., Jeong, S. C., Gunduz, I., Tucker, D. M., Buss, G. R., and Tolin, S. A. 2008. Pyramiding of Soybean mosaic virus resistance genes by marker-assisted selection. Crop Sci. 48:517-526.

29. Schmitthenner, A. F. 1999. Phytophthora root rot. Page 100 in: Compendium of Soybean Diseases, 4th ed. G. L. Hartman, J. B. Sinclair, and J. C. Rupe, eds. American Phytopathological Society, St. Paul, MN.

30. Slaminko, T. L., Bowen, C. R., and Hartman, G. L. 2010. Multi-year evaluation of commercial soybean cultivars for resistance to Phytophthora sojae. Plant Dis. 94:368-371.

31. Srinivasan, I., and Tolin, S. A. 1992. Detection of three viruses of clovers by direct tissue immunoblotting. Phytopathology 82:821-826.

32. Venette, R., and Ragsdale, D. 2004. Assessing the invasion by soybean aphid (Homoptera: Aphididae): Where will it end? Ann. Entomol. Soc. Am. 97:219-226.

33. Wang, Y., Hobbs, H. A., Bowen, C. R., Bernard, R. L., Hill, C. B., Haudenshield, J. S., Domier, L. L., and Hartman, G. L. 2006. Evaluation of soybean cultivars, 'Williams' isogenic lines, and other selected soybean lines for resistance to two Soybean mosaic virus strains. Crop Sci. 46:26492653.

34. Wang, Y., Hobbs, H. A., Hill, C. B., Domier, L. L., Hartman, G. L., and Nelson, R. L. 2005. Evaluation of ancestral lines of U.S. soybean cultivars for resistance to four soybean viruses. Crop Sci. 45:639-644. 